\title{
PENGARUH PROMOSI DAN KEPUASAN NASABAH TERHADAP PENINGKATAN PEMASARAN KARTU KREDIT PADA PT. BANK MEGA Tbk. CABANG MAKASSAR
}

\author{
Muhammad Ashari Asri \\ (Mahasiswa STIE AMKOP Makassar) \\ Sofyan Hamid Indar \\ (Dosen STIE AMKOP Makassar) \\ Abdul Karim \\ (Dosen STIE AMKOP Makassar)
}

\begin{abstract}
ABSTRAK
Penelitian ini bertujuan untuk mengetahui pengaruh promosi dan kepuasan nasabah terhadap pemasaran kartu kredit Bank Mega, baik secara Parsial dan Simultan.

Penelitian ini menggunakan Sampel sebanyak 30 orang responden, dimana responden tersebut akan dimintai tanggapan mengenai pertanyaan-pertanyaan dalam kuisioner yang dibagikan, penelitian ini juga menggunakan Software SPSS.21 sebagai alat untuk menghitung data yang akan digunakan.

Hasil Penelitian yang ditemukan bahwa promosi berpegaruh negatif dan signifikan terhadap penjualan kartu kredit Bank Mega sedangkan kepuasan nasabah berpengaruh dan signifikan terhadap kartu kredit Bank Mega sedangkan pada uji bersamaan antara variabel promosi dan kepuasan nasabah berpengaruh signifikan terhadap penjualan kartu kredi pada Bank Mega Cabang Makassar

Kata Kunci : Promosi, Kepuasan Nasabah, Pemasaran Kartu Kredit
\end{abstract}

\begin{abstract}
This study aims to determine the effect of promotion and customer satisfaction to Mega Bank credit card marketing, both partial and simultaneous.
\end{abstract}


This study uses a sample of 30 respondents, where respondents will be asked for feedback on the questions in the questionnaire were distributed, this research also use Software SPSS.21 as a tool to calculate the data to be used.

Research found that having an negative and significant promotion of the sale of Mega Bank credit card while the customer satisfaction and significant effect on the Mega Bank credit card while at the same test between variables promotion and customer satisfaction significantly influence kredi card sales at Bank Mega Branch Makassar Keywords: Promotion, Customer Satisfaction, Marketing Credit Cards

\section{PENDAHULUAN}

Pada tahun 2017 sudah berjalan hampir tiga pekan. Di awal tahun, bank-bank penyedia kartu kredit biasanya berlomba-lomba menggelar promo kartu kredit yang bisa dimanfaatkan oleh para pemegang kartu kredit. Anda perlu selalu up-to-date dengan informasi promo kartu kredit agar manfaat kartu kredit dapat Anda maksimalkan.

Berdasarkan catatan HaloMoney.co.id, ada banyak promo baru yang digelar bank-bank penyedia kartu kredit di awal tahun 2017 ini. Sayang sekali bila terlewatkan. Karena, bisa jadi salah satunya adalah kartu kredit Anda saat ini. Sedang bagi Anda yang belum menjadi nasabah kartu kredit, tidak ada salahnya memanfaatkan tawaran promo itu dengan mengajukan diri menjadi pemegang kartu kredit sekarang juga.

Meningkatnya intensitas persaingan dan jumlah pesaing menuntut setiap bank untuk memperhatikan kebutuhan dan keinginan nasabahnya serta berusaha memenuhi apa yang mereka harapkan dengan cara yang lebih unggul serta lebih memuaskan dari pada yang dilakukan oleh pihak bank dan pesaing lainnya. Sehingga perhatian bank tidak hanya terbatas pada produk barang atau jasa yang dihasilkan saja, tetapi juga pada aspek proses, sumber daya manusia, serta lingkungannya. 
Tentunya dalam menjalankan aktifitas perusahaan yang bergerak dibidang usaha barang dan jasa sering kali promosi menjadi hal terpenting dalam aktifitasnya. Terlepas dari hal itu dikarenakan promosi merupakan bagian penting dari strategi penjualan,karena promosi digunakan pemasar dalam menginformasikan dan mempengaruhi orang atau pihak lain sehingga konsumen tertarik untuk melakukan transaksi atau pertukaran produk barang atau jasa yang dipasarkannya.

Terlepas dari hal di atas, kini perusahaan juga melihat kondisikondisi dimana kepuasan konsumen yang bisa memberikan peluang memberikan hal yang terbaik bagi konsumennya. Tentunya dengan adanya kepuasan konsumen yang baik akan memberikan dampak yang baik pula pada perusahaan.

Kepuasan konsumen merupakan isu yang kritikal di semua industri jasa dan perdagangan. Pengukuran kepuasan pengguna adalah sebagian dari usaha terpadu yang dapat memperbaiki kualitas produk, dan menghasilkan daya saing yang kompetitif, memicu pembelian awal, dan akhirnya dapat memberikan persepsi konsumen yang baik terhadap perusahaan. Teori Perilaku konsumen menunjukkan bahawa perilaku pembelian konsumen dan tingkat kepuasan adalah dipengaruhi oleh latar belakang konsumen, ciri-ciri dan stimulasi keluaran (Choi dan Chu 2005).

Dalam artikel The New soul and Structure of The Post Management Corporation, Ricard Koch dan Ian Godden memperkirakan pada masa yang akan datang para pelanggan akan semakin memegang peran kunci keberhasilan perusahaan. ini memaksa perusahaan-perusahaan untuk lebih beorientasi eksternal dengan cara memberikan pelayanan dengan mutu sebaik mungkin kepada para pelanggan mereka, sehingga mereka akan merasa puas dan loyal.

Dalam konteks teori permintaan konsumen kepuasan lebih banyak didefenisikan dari perspektif pengalaman konsumen setelah mengkonsumsi atau menggu-nakan suatu produk atau jasa. Dengan demikian kepuasan dapa diartikan sebagai hasil dari penilaian (persepsi 
konsumen bahwa produk atau pelayanan telah memberikan tingkat kenikmatan di mana tingka pemenuhan ini bisa lebih atau kurang. Tingka kenikmatan yang dimaksud disini adalah kesesuaian antara apa yang dirasakan oleh konsumen dari pengalaman konsumsinya dengan apa yang diharapkannya. Dalam pengertian di atas yang terpenting adalah persepsi, bukan kondisi aktual. Dengan demikian, bisa terjadi bahwa secara aktual, suatu produk atau jasa mempunyai potensi untuk memenuhi harapan pelanggan tetapi ternyata hasil dari persepsi pelanggan tidak sama dengan apa yang diinginkan oleh produsen. Ini bisa terjadi karena adanya gap antara apa yang dipersepsikan oleh produsen (perusahaan) dengan apa yang dipersepsikan oleh pelanggan.

Dalam hal ini PT. Bank Mega Tbk. Cabang Makassar yang bergerak dibidang perbankan juga memandang perlu pendekatan kepuasan nasabahnya sebagai pengguna dalam kartu kredit pada Bank Mega. Dengan demikian tentunya apa yang menjadi ukuran tentang promosi dan lingkungan kerja belumlah menjadi satu ukuran atau jaminan terhadap peningkatan penjualan perusahaan.

Sebagai langkah awal dari upaya mendefinisikan tuntutan nasabah, maka hal yang harus diperhatikan dan tidak dapat dipisahkan adalah ketersediaan informasi yang menyangkut persepsi dan harapan nasabah terhadap layanan yang ditawarkan oleh pihak bank. Untuk itulah maka perlu dianalisis sejauh mana nasabah merasa puas dengan pelayanan yang telah diterimanya.

PT. Bank Mega. Tbk memandang dalam setiap perubahan sikap konsumennya haruslah menjadi bahan untuk dievaluasi, promosi yang telah diberikan dalam bentuk belanjadi swalayan-swalayan dengan menggunakan kartu kredit bank mega apakah itu memberikan dampak penggunaan kartu kredit pada Bank Mega. Terlihat bahwa secara banyak juga orang ketika berbelanja menggunakan uang tunai sebagai alat pembayarannya. 
Adanya komplain dari nasabah pengguna kartu kredit Bank Mega dalam melakukan transaksi sering kali terjadi, sehingga dalam hal tersebut mengurangi intensitas penggunaan kartu kredit pada Bank Mega dalam melakukan transaksi, sehingga pihak Bank Mega sangatlah penting dalam memberikan kepuasan kepada nasabah pengguna kartu kreditnya.

Dari gambaran diatas menunjukkan bahwa dengan bahwa terkadang promosi-promosi penggunaan kartu kredit tidalah menjadi satu bagian penting dalam nasabah melakukan transaksi penggunaan kartu kredit, adanya komplain nasabah dalam menggunakan kartu kredit juga menjadi bagian terpenting dalam memberikan suatu kepuasan nasabah.

\section{METODE PENELITIAN}

\section{Desain dan Pendekatan Penelitian}

Penelitian ini menjelaskan hubungan mempengaruhi dan dipengaruhi dari variabel-variabel yang akan diteliti. Dengan menggunakan pendekatan kuantitatif, karena data yang akan digunakan untuk menganalisis hubungan antar variabel dinyatakan dengan angka atau skala numerik. Penelitian ini menganalisis pengaruh Promosi, dan Kepuasan Nasabah terhadap Pemasaran Kartu Kredit pada PT. Bank Mega Tbk Cabang Makassar.

\section{Lokasi dan Waktu Penelitian}

Penelitian ini akan dilaksanakan di PT. Bank Mega Tbk Cabang Makassar, Adapun waktu penelitian yang akan dilaksanakan pada bulan September 2017 sampai dengan November 2017.

\section{Instrumen Penelitian}

Di penelitian ini, peneliti akan menggunakan satu instrumen yaitumenggunakan bantuan software SPSS. SPSS (Statistical Product and Service Solution) adalah sebuah program komputer yang digunakan untuk menganalisis statistika. Adapun teknik analisis data dalam penelitian ini menggunakan pengujian validitas dan reabilitas.

1. Uji Validitas 
Uji validitas digunakan untuk mengetahui tingkat kevalidan dari instrument (kuesioner) yang digunakan dalam pengumpulan data. Suatu kuesioner dikatakan valid jika pertanyaan pada kuesioner mampu untuk mengungkapkan sesuatu yang akan diukur oleh kuesioner tersebut (Ghozali, 2011:97).

Tinggi rendahnya validitas suatu instrumen kuesioner dapat diukur melalui faktor loading dengan bantuan computer SPSS. Faktor loading adalah korelasi item-item pertanyaan dengan konstruk yang diukurnya. Jika nilai faktor loading lebih besar atau sama dengan $0,5(\geq 0,5)$ maka indikator yang dimaksud valid dan berarti bahwa indikator tersebut signifikan dalam mengukur suatu konstruk. Untuk menguji apakah terdapat korelasi antar variabel digunakan UjiBartlett Test of Spericity. Jika hasilnya signifikan $\geq 0,5$ berarti matrik korelasi memiliki korelasi signifikan dengan sejumlah variabel.

2. Uji Reabilitas

Uji reliabilitas adalah pengujian yang dilakukan untuk mengetahui sejauh mana pengukuran tersebut tanpa bias dan menjamin pengukuran yang konsisten lintas waktu dan lintas beragam item dalam instrumen (Sekaran, 2009). Untuk mengukur reliabilitas instrumen dilakukan dengan menggunakan nilai koefisien cronbach's alpha yang mendekati 1 menandakan reliabilitas dengan konsistensi yang tinggi.

Indikator pengukuran reliabilitas menurut Sekaran (2009) yang membagi tingkatan reliabilitas dengan kriteria alpha sebagai berikut:
a. $0.80-1,0=$ Reliabilitas Baik
b. $0,60-0,79=$ Reliabilitas Diterima
c. $<0,60=$ Reliabilitas Buruk 


\section{Teknik Pengumpulan Data}

Teknik yang digunakan untuk mengumpulkan data dalam penelitian ini adalah:

a) Observasi, yaitu teknik pengumpulan data yang dilakukan melalui pengamatan langsung dilapangan agar memperoleh data primer yang diharapkan.Sugiyono (2010:86), skala Likert dapat digunakan untuk mengukur sikap, pendapat dan persepsi seseorang atau kelompok orang tentang fenomena tertentu. Angket dalam penelitian ini menggunakan skala Likert dengan lima pilihan jawaban, yaitu :

1 = Sangat Tidak Setuju (STS)

2 = Tidak Setuju (TS)

3 = Ragu-ragu $(\mathrm{R})$

4 = Setuju (S)

5 = Sangat Setuju (S)

b) Kuesioner, yang memberikan daftar pertanyaan kepada responden, dan dari hasil kuisioner tersebut akan di tabulasi.

c) Dokumentasi, yaitu pengumpulan data melalui laporan-laporan tertulis atau catatan-catatan yang menjadi agenda kebijakan, serta dengan cara penelitian pustaka, agar memperoleh data sekunder yang diharapkan.

d) Wawancara, yaitu teknik pengumpulan data yang dilakukan dengan tanya jawab secara langsung dengan responden, agar diperoleh data primer maupun data skunder yang diharapkan.

\section{Teknik Analisis Data Dan Uji Hipotesis}

Dalam penelitian ini, metode analisa digunakan untuk mengetahui pengaruh promosi dan kepuasan nasabah terhadap pemasaran kartu kredit adalah dengan menggunakan analisis statistik/uji statistik.

Di dalam penelitian data mempunyai kedudukan yang paling tinggi, karena data merupakan penggambaran variabel yang diteliti, dan berfungsi sebagi alat pembuktian hipotesis. Oleh karena itu benar 
tidaknya data, sangat menentukan bermutu tidaknya hasil penelitian. Dalam penelitian ini teknik analisis data yang digunakan sebagai berikut:

\section{Uji Linieritas}

Linieritas adalah keadaan dimana hubungan antara variabel terikat dengan variabel bebas bersifat linier (garis lurus) dalam range variabel bebas tertentu. Menurut Sugiono dan Siagian (2010:227)." Untuk memberikan gambaran hubungan dua variabel, sebelum mengetahui apakah berhubungan linier atau tidak sebaiknya dilakukan plotting (tebaran titik) terhadap pasangan nilai-nilai $\mathrm{X}$ dan $\mathrm{Y}$.

\section{Analisis Regresi Linier Berganda}

Untuk menghitung besarnya pengaruh variable $\mathrm{X}$ terhadap variable Y maka dilakukan perhitungan dengan menggunakan metode analisa regresi linear berganda. Dalam penelitian ini metode tersebut digunakan untuk mengetahui seberapah besar pengaruh promosi (X1) dan kepuasan nasabah (X2) secara kuantitatif berpengaruh terhadap pemasaran kartu kredit (Y). Priyatno (2008:73-88) secara umum formulasi dari regresi berganda dapat ditulia sebagai berikut :

$$
Y=b o+b_{1} X_{1}+b_{2} X_{2}+e
$$

Dimana :

$$
\begin{array}{ll}
\mathrm{Y} & =\text { Pemasaran Kartu Kredit } \\
\mathrm{bo} & =\text { Konstanta } \\
\mathrm{b}_{1} \mathrm{~b}_{2} \mathrm{~b}_{3} & =\text { Koefisien Regresi } \\
\mathrm{X} 1 & =\text { Promosi } \\
\mathrm{X} 2 & =\text { Kepuasan Nasabah } \\
\mathrm{e} & =\text { Kesalahan penganggu }
\end{array}
$$

\section{Data Uji Hipotesis}

Menurut M. Iqbal Hasan (2009:54) pengujian hipotesis adalah suatu prosedur yang akan menghasilkan suatu keputusan, yaitu keputusan menerima atau menolak hipotesis tersebut. Hipotesis dapat dijadikan 
sebagai petunjuk kearah penyelidikan lebih lanjut. Oleh karena itu, hipotesis harus diuji kebenarannya melalui uji statistik.

Hipotesis yang akan diuji dalam penelitian ini adalah ada atau tidaknya pengaruh yang positif dan signifikan dari promosi (variabel $\mathrm{X} 1$ ) dan kepuasan nasabah (variabel X2) terhadap pemasaran kartu kredit (variabel Y) untuk menguji variabel tersebut maka digunakan uji sebagai berikut:

1. Uji $F$

Digunakan untuk mengetahui pengaruh bersama-sama (simultan) variabel bebas terhadap varibel terikat.

2. Uji t

Digunakan untuk mengetahui apakah masing-masing variabel bebasnya secara sendiri-sendiri berpengaruh secara signifikan terhadap variabel terikatnya.

\section{HASIL PENELITIAN}

\section{Uji Validitas dan Rentabilitas}

Adapun uji validitas dari variabel yang penulis gunakan dalam penelitian, terlihat pada tabel uji validitas dari setiap variabel yang digunakan, berikut ini :

Tabel 16

Uji Validitas instrumen Variabel Promosi (X1)

\begin{tabular}{|c|c|c|c|c|}
\hline $\begin{array}{c}\text { Item } \\
\text { Pertanyaan }\end{array}$ & $\begin{array}{c}\text { Nilai } \\
\text { koefisien }\end{array}$ & Tabel $r$ & Sig & Keterangan \\
\hline Item 1 &, 834 & 0,3673 &, 000 & Valid \\
\hline Item 2 &, 820 & 0,3673 &, 000 & Valid \\
\hline Item 3 &, 739 & 0,3673 &, 000 & Valid \\
\hline
\end{tabular}

Sumber Data : Data diolah,SPSS.2017

Dari data diatas, maka dapat jelaskan dasar pengambilan keputusannya sebagai berikut : 
a. Jika nilai $r_{\text {hitung }}>$ rtabel maka instrumen data dikatakan valid

b. Jika nilai rhitung $<r_{\text {tabel }}$ maka instrumen data dikatakan tidak valid

Untuk mendapatkan rtabel, maka penulis akan menghitung nilai df, dimana jumlah responden sebanyak 30 orang, dengan taraf signikansi $5 \%$. Artinya untuk menentukan $\mathrm{df}=$ jumlah responden dikurangi dengan variabel yang digunakan, maka df $=30-3=27$, jadi df : 27 kemudian akan dicari pada $\mathrm{R}$ statistik dengan urutan df : 27 dengan signifikasi 5\%, ditemukan hasil 0,3673. Maka dari dasar ini kemudian dapat diketahui bahwa :

1. Untuk pertanyaan 1 nilai rhitung $0,834>$ dari $r_{\text {tabel }} 0,3673$, dengan taraf siknifikansi $0,000<$ dari 0,05, maka pertanyaan 1 dikatakan valid

2. Untuk pertanyaan 2 nilai $r_{\text {hitung }} 0,820>$ dari $r_{\text {tabel }} 0,3673$, dengan taraf siknifikansi $0,000<$ dari 0,05, maka pertanyaan 2 dikatakan valid

3. Untuk pertanyaan 3 nilai rhitung $0,739>$ dari rtabel 0,3673, dengan taraf siknifikansi $0,000<$ dari 0,05, maka pertanyaan 3 dikatakan valid

Dari data ini kemudian penulis menarik kesimpulan untuk validitas instrumen variabel promosi (X1) di katakan valid.

Berikutnya untuk validitas variabel kepuasan nasabah (X2) sebagai berikut :

Tabel 17

Uji Validitas instrumen Variabel Promosi (X1)

\begin{tabular}{|c|c|c|c|c|}
\hline $\begin{array}{c}\text { Item } \\
\text { Pertanyaan }\end{array}$ & $\begin{array}{c}\text { Nilai } \\
\text { koefisien }\end{array}$ & Tabel r & Sig & Keterangan \\
\hline Item 1 &, 668 & 0,3673 &, 000 & Valid \\
\hline Item 2 &, 782 & 0,3673 &, 000 & Valid \\
\hline Item 3 &, 683 & 0,3673 &, 000 & Valid \\
\hline Item 4 &, 686 & 0,3673 &, 000 & Valid \\
\hline Item 5 &, 856 & 0,3673 &, 000 & Valid \\
\hline
\end{tabular}

Sumber Data : Data diolah,SPSS.2017 
Dari data diatas, maka dapat jelaskan dasar pengambilan keputusannya sebagai berikut :

c. Jika nilai $r_{\text {hitung }}>$ rtabel maka instrumen data dikatakan valid

d. Jika nilai $r_{\text {hitung }}<$ rabel maka instrumen data dikatakan tidak valid Untuk mendapatkan rtabel, maka penulis akan menghitung nilai df, dimana jumlah responden sebanyak 30 orang, dengan taraf signikansi $5 \%$. Artinya untuk menentukan $\mathrm{df}=$ jumlah responden dikurangi dengan variabel yang digunakan, maka df $=30-3=27$, jadi df : 27 kemudian akan dicari pada $\mathrm{R}$ statistik dengan urutan df : 27 dengan signifikasi $5 \%$, ditemukan hasil 0,3673 . Maka dari dasar ini kemudian dapat diketahui bahwa :

1. Untuk pertanyaan 1 nilai rhitung $0,668>$ dari rtabel 0,3673 , dengan taraf siknifikansi $0,000<$ dari 0,05 , maka pertanyaan 1 dikatakan valid

2. Untuk pertanyaan 2 nilai rhitung $0,782>$ dari rtabel 0,3673 , dengan taraf siknifikansi $0,000<$ dari 0,05, maka pertanyaan 2 dikatakan valid

3. Untuk pertanyaan 3 nilai rhitung $0,683>$ dari rtabel 0,3673 , dengan taraf siknifikansi $0,000<$ dari 0,05 , maka pertanyaan 2 dikatakan valid.

4. Untuk pertanyaan 3 nilai rhitung $0,686>$ dari rtabel 0,3673 , dengan taraf siknifikansi $0,000<$ dari 0,05 , maka pertanyaan 4 dikatakan valid

5. Untuk pertanyaan 3 nilai rhitung $0,856>$ dari rtabel 0,3673 , dengan taraf siknifikansi $0,000<$ dari 0,05 , maka pertanyaan 5 dikatakan valid

Dari data ini kemudian penulis menarik kesimpulan untuk validitas instrumen variabel kepuasan nasabah (X2) di katakan valid.

Selain dari uji validitas, maka penulis juga melakukan uji reabilitas terhadap data yang di analisi berikut hasil uji reabilitas dari yang dilakukan dengan SPSS.21 terlihat datanya pada tabel berikut : 
Tabel 18

Uji Reabilitas promosi (X1) dan kepuasan nasabah (X2)

\begin{tabular}{|c|c|c|c|c|}
\hline Variabel & $\begin{array}{c}\text { Cronbach's } \\
\text { Alpha }\end{array}$ & Standardized & Sig & Keterangan \\
\hline X1 &, 815 & 0,60 &, 000 & Realibel \\
\hline X2 &, 788 & 0,60 &, 000 & Realibel \\
\hline
\end{tabular}

Sumber Data : Data diolah dari SPSS.21.2017

Dari tabel 18 di atas dapat ditarik kesimpulan dari data yang telah di sajikan bahwa :

1. Jika Cronbach's Alpha $>$ Standardized $(0,60)$, maka data dikatakan realibel

2. Jika Cronbach's Alpha < Standardized $(0,60)$, maka data dikatakan tidak realibel

Jadi kesimpulan yang dapat di ambil dari pengolahan data melalui spss. 21 adalah :

1. Untuk variabel promosi (X1) menunjukkan bahwa Cronbach's Alpha 0,815 > Standardized $(0,60)$, maka data dikatakan realibel.

2. Untuk variabel kepuasan nasabah (X2) menunjukkan bahwa Cronbach's Alpha 0,788 > Standardized (0,60), maka data dikatakan realibel.

Dari penjelasan uji data validitas dan reabilitas, maka dapatlah kita melakukan analisis regresi dari data yang telah di uji validitas dan reabilitasnya.

\subsection{Uji Regresi Berganda}

Pada analisis ini penulis ingin mengetahui pengaruh secara parsial dan simultan dari variabel independen terhadap dependen. Untuk lebih lengkapnya,penulis akan menyajikan data hasil olahan melalui SPSS.21 berikut ini : 
Tabel 19

Hasil Run SPSS

Coefficients $^{\mathrm{a}}$

\begin{tabular}{|c|c|c|c|c|c|}
\hline \multirow[t]{2}{*}{ Model } & \multicolumn{2}{|c|}{$\begin{array}{l}\text { Unstandardized } \\
\text { Coefficients }\end{array}$} & \multirow{2}{*}{$\begin{array}{c}\text { Standardiz } \\
\text { ed } \\
\text { Coefficient } \\
\text { s } \\
\text { Beta } \\
\end{array}$} & \multirow[t]{2}{*}{$\mathrm{t}$} & \multirow[t]{2}{*}{ Sig. } \\
\hline & B & Std. Error & & & \\
\hline (Constant) & 6,468 & 5,211 & & 1,241 & ,225 \\
\hline $\begin{array}{l}\text { Promosi } \\
\text { Kepuasan } \\
\text { Nasabah }\end{array}$ & $\begin{array}{r}-1,059 \\
, 937\end{array}$ & $\begin{array}{l}\text {, 498 } \\
\text {,279 }\end{array}$ & $\begin{array}{r}-, 431 \\
, 680\end{array}$ & $\begin{array}{r}-2,126 \\
3,354\end{array}$ & $\begin{array}{l}, 043 \\
, 002\end{array}$ \\
\hline
\end{tabular}

Sumber data : SPSS.21.2018

Dari tabel 19 yang telah diolah melalui SPSS.21 di atas, maka dari data tersebut akan dimasukan kedalam persamaan sebagai berikut :

$$
Y=b o+b_{1} X_{1}+b_{2} X_{2}
$$

Dimana

$$
Y=6,468+(1,056)+0,937
$$

Dari persamaan diatas, maka diketahui nilai yang ditemukan adakan diinterpretasikan sebagai berikut :

1. $b 0=6,468$ dimana jika tidak ada perubahan pada fitur, durasi dan aktivitas, maka penjualan sebesar 6,468 sebagai nilai konstans untuk variabel terikat.

2. $b 1=(1,056)$ artinya setiap perubahan promosi akan mempengaruhi penjualan sebesar $(1,056)$.

3. $b 1=0,937$ artinya setiap perubahan durasi akan mempengaruhi penjualan sebesar 0,937

Dari olah data yang dilakukan ditemukan bahwa hasil regresi menunjukkan bahwa promosi berpengaruh negarif sedangkan kepuasan nasabah berpengaruh positif terhadap penjualan.

Untuk mengetahui besaran pengaruh dari variabel yang diteliti, maka penulis melakukan uji koefisien determinasi. Dimana koefisien 
determinasi $\left(R^{2}\right)$ pada intinya mengukur seberapa jauh kemampuan model dalam menerangkan variabel dependennya. Nilai Koefisien Determinasi $\left(R^{2}\right)$ yang mendekati satu berarti variabel-variabel independennya menjelaskan hampir semua informasi yang dibutuhkan untuk memprediksi variabel dependen ( Ghozali,2009).

Dari data yang telah diolah melalui SPSS.21 ditemukan hasil perhitungan Koefisien Determinasi $\left(R^{2}\right)$ pada penelitian ini dapat terlihat pada tabel berikut ini :

Tabel 20

Hasil Run Model Summary

Model Summary

\begin{tabular}{|c|c|c|c|c|c|c|}
\hline \multirow{2}{*}{$\begin{array}{l}\text { Mod } \\
\text { el }\end{array}$} & \multirow[t]{2}{*}{$\mathrm{R}$} & \multirow{2}{*}{$\begin{array}{c}\mathrm{R} \\
\text { Square }\end{array}$} & \multirow{2}{*}{$\begin{array}{c}\text { Adjusted R } \\
\text { Square }\end{array}$} & \multirow{2}{*}{$\begin{array}{l}\text { Std. Error } \\
\text { of the } \\
\text { Estimate }\end{array}$} & \multicolumn{2}{|c|}{ Change Statistics } \\
\hline & & & & & $\begin{array}{l}\text { R Square } \\
\text { Change }\end{array}$ & $\begin{array}{c}\mathrm{F} \\
\text { Change }\end{array}$ \\
\hline 1 &, $543^{a}$ & ,294 & ,242 & 3,079 & ,294 & 5,632 \\
\hline
\end{tabular}

Sumber data : SPSS.21.2018

Dari tabel di atas, olah data menunjukkan bahwa hasil perhitungan yang diperoleh dari nilai koefisien determinasi $\left(R^{2}\right)$ sebesar 0,294 yang diinterpretasikan bahwa variabel yang diteliti memiliki hubungan sebesar $29,4 \%$, artinya bahwa komunikasi interpersonal dipengaruhi oleh variabel fitur, durasi dan aktivitas sedangkan 70,6\% merupakan faktor-faktor lain yang tidak diteliti dalam penelitian ini.

\subsection{Uji T dan Uji F}

Untuk dapat menjawab hipotesi yang diajukan dalam penelitian ini, maka untuk mengetahui pengaruh dari masing-masing variabel independen terhadap variabel dependen penulis melakukan Uji T.

Adapun hasil regresi data yang digunakan untuk diinterpretasikan dalam penelitian ini sebegai berikut : 
Tabel 21

Hasil Run Koefisien

Coefficients $^{\mathrm{a}}$

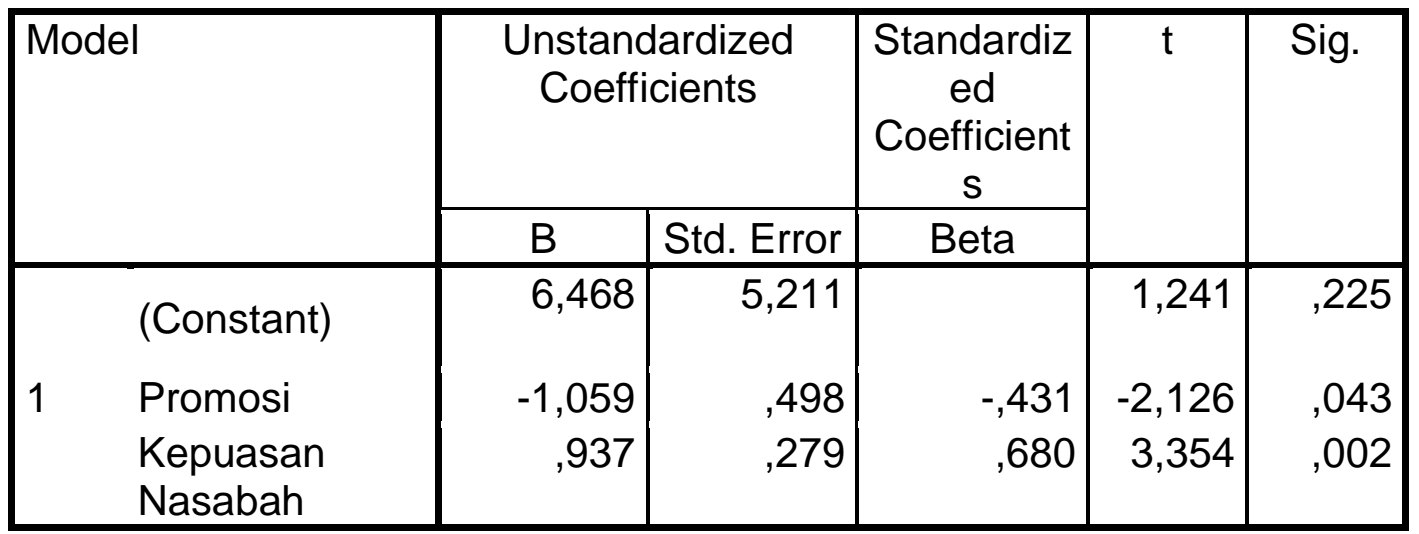

Sumber data : SPSS.21.2018

Sebelum penulis menginterpretasikan data pada tabel di atas, maka dipandang perlu untuk mengetahui dasar pengambilan keputusan untuk menjawab hipotesis sebagai berikut:

1. Jika nilai $t$ hitung $>t$ tabel maka variabel bebas $(X)$ berpengaruh terhadap variabel terikat $(\mathrm{Y})$.

2. Jika nilai $\mathrm{t}$ hitung $<\mathrm{t}$ tabel maka variabel bebas $(\mathrm{X})$ tidak berpengaruh terhadap variael terikat $(\mathrm{Y})$.

Berdasarkan nilai signifikansi hasil output SPSS

1. Jika nilai Sig. $<0,05$ maka variabel bebas $(X)$ berpengaruh signifikan terhadap variabel terikat $(\mathrm{Y})$.

2. Jika nilai Sig. $>0,05$ maka variabel bebas $(X)$ tidak berpengaruh signifikan terhadap variabel terikat $(\mathrm{Y})$.

Untuk melihat $t$ tabel dalam pengujian hipotesis pada model regresi, perlu menentukan derajat bebas atau degree of freedom dan hal ini ditentukan dengan rumus: $\mathrm{Df}=\mathrm{n}-\mathrm{k}$,

a. Dimana $\mathrm{n}=$ Banyaknya observasi dalam kurun waktu data.

b. Dimana $\mathrm{k}=$ Banyaknya variabel (bebas dan terikat).

Pada analisis regresi digunakan probabilitas 2 sisi, maka untuk mencari nilai tabel distribusi t dicari pada $a=5 \%: 2=2,5 \%$ (uji 2 sisi) 
dengan derajat kebebasan (df) $n-k$ atau $30-3=27$ ( $n$ adalah jumlah kurun waktu pada observasi dan $\mathrm{k}$ adalah jumlah variabel). Dengan pengujian 2 sisi (signifikansi $=0,025$ ) hasil diperoleh untuk $\mathrm{t}$ tabel sebesar 2,052.

Maka dari data yang tertera pada tabel dapat interpretasikan sebagai berikut :

1. Bahwa thitung dari variabel promosi $(X 1)$ yaitu sebesar $(2,126)$, maka dari dasar pengambilan keputusan didapatkan $t$ nitung $>t$ tabel atau $(2,126)>2,052$ dengan taraf siknifikasi 0,042 <0,05, dalam artian bahwa variabel promosi (X1) memiliki pengaruh negatif dan signifikan terhadap penjualan.

2. Bahwa thitung dari variabel kepuasan nasabah (X2) yaitu sebesar 3,354 , maka dari dasar pengambilan keputusan didapatkan $t$ hitung $>$ $\mathrm{t}$ tabel atau 3,354 $>2,052$ dengan taraf siknifikasi 0,002 $<0,05$, dalam artian bahwa variabel kepuasan nasabah (X2) memiliki pengaruh dan signifikan terhadap penjualan.

Penjelasan di atas, menunjukkan bahwa variabel promosi memiliki pengaruh negatif dan signifikansi, sedangkan variabel durasi kepuasan nasabah memiliki pengaruh postifi dan signifikan terhadap penjualan. Untuk variabel yang memiliki pengaruh dominan terhadap penjualan adalah variabel kepuasan nasabah $t$ hitung $>t$ tabel atau 3,354 >2,052 dengan taraf siknifikasi 0,002 $<0,05$.

Sedangkan untuk menguji pengaruh semua atau secara bersamasama (simultan) variabel independen terhadap variabel dependen, maka penulis melakukan uji $\mathrm{F}$ berikut ini : 
Tabel 22

Hasil Run Anova

ANOVAa

\begin{tabular}{|rl|r|r|r|r|l|}
\hline \multicolumn{1}{|l|}{ Model } & \multicolumn{1}{|c|}{$\begin{array}{c}\text { Sum of } \\
\text { Squares }\end{array}$} & df & $\begin{array}{c}\text { Mean } \\
\text { Square }\end{array}$ & $\mathrm{F}$ & Sig. \\
\hline 1 & Regression & 106,795 & 2 & 53,397 & 5,632 &, $009^{\mathrm{b}}$ \\
& Residual & 256,005 & 27 & 9,482 & & \\
\cline { 2 - 4 } & 362,800 & 29 & & & \\
\hline
\end{tabular}

Sumber data : Hasil Run.SPSS.21.2018

Untuk dapat menginterpretasikan Uji F dalam penelitan ini maka perlu dasar pengambilan keputusan dalam uji $F$ sebagai berikut :

1. Jika nilai signifikansi $<0,05$ maka variabel independent secara bersama-sama berpengaruh signifikansi terhadap variabel dependent.

2. Jika nilai signifikansi $>0,05$ maka variabel independent secara bersama-sama tidak berpengaruh signifikansi terhadap variabel dependent.

Untuk dasar pengambilan keputusan dalam Uji F berdasarkan nilai Fhitung dan $\mathrm{F}_{\text {Tabel }}$ sebagai berikut :

1. Jika F hitung $>F_{\text {Tabel }}$ maka variabel independent (bebas) secara simultan berpengaruh terhadap variabel dependent (terikat)

2. Sebaliknya, Jika $F_{\text {hitung }}<\mathrm{F}_{\text {Tabel }}$ maka variabel independent (bebas) secara simultan tidak berpengaruh terhadap variabel dependent (terikat).

Dari output di atas, diperoleh Fhitung sebesar 5,632. Langkah selanjutnya mencari $F_{\text {tabel }}$ dan membandingkan dengan $F_{\text {hitung 5,632. }}$ Dengan menggunakan rumus $F_{\text {tabel }}$ adalah $(k ; n-k)$. Dimana $(k)$ ada jumlah variabel independent (bebas) dan ( $n$ ) adalah jumlah responden atau sampel penelitian. Maka diketahui bahwa $(k=2)$ dan $(n=30)$ hasilnya adalah $(2 ; 30-2)=(3 ; 28)$. Dari hasil tersebut ditemukan $\mathrm{F}_{\text {tabel }}$ pada baris 2 dan kolom 28 sebesar 3,34.

Dari dasar pengambilan keputusan di atas, maka dapat di

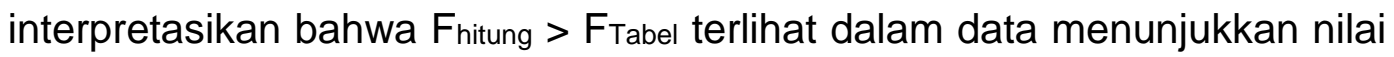




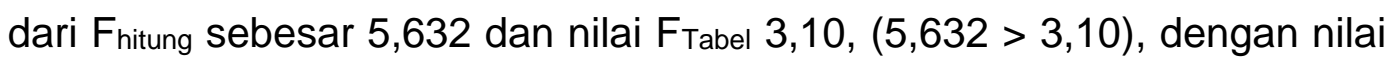
probabilita $0,009<0,05$. Maka dari data tersebut dapat dikatakan bahwa variabel promosi (X1) dan variabel kepuasan nasabah (X2) secara bersama-sama berpengaruh terhadap variabel penjualan $(\mathrm{Y})$.

\section{PEMBAHASAN}

Dari hasil yang telah dipaparkan di atas, maka penulis akan memberikan pembahasan terhadap hasil penelitian yang telah ada sebagai berikut :

Dari hasil di atas, terlihat bahwa promosi pada PT. Bank Mega Cabang Makassar memiliki pengaruh terhadap penjualan kartu kredit, namun pengaruhnya negatif dengan nilai signifikansi 0,042 lebih kecil dari 0,05 , hal ini dikerenakan pengguna kartu tidak lagi melihat sisi promosi penawaran yang berbeda dari Bank Mega, artinya walaupun tanpa promosi yang besar-besar kartu kredit pada Bank Mega, nasabah tetap mengunakan atau merekomendasikan kartu kredit Bank Mega dikarenakan kartu kredit Bank mega sudah menjadi kepercayaan bagi pengguna kartu. Tentunya dengan adanya kepercayaan yang dimiliki akan tetap memberikan hasil terhadap Bank Mega dalam melakukan promosi.

Penelitian ini didukung oleh penelitian yang dilakukan oleh Tri Novi Sriwijayani (2008) yang mengatakan bahwa variabel bauran pemasaran yang terdiri dari harga, tempat, layanan purna jual memiliki pengaruh positif dan signifikan terhadap keputusan konsumen memiliki kartu kredit Bank BRI, sedangkan variabel produk dan promosi tidak memiliki pengaruh terhadap keputusan memilih kartu kredit BRI

Dari hasil ditemukan bahwa kepuasan nasabah berpengaruh positif dan signifikan terhadap pemasaran kartu kredit Bank Mega cabang Makassar, hal ini dikarenakan bahwa segala kebutuhan pengguna kartu kredit dapat tercapai, dalam artian bahwa nasabah yang merasakan puas akan memberikan rekomendasi kepada orang-orang lain untuk 
menggunakan kartu kredit Bank Mega, disini terlihat bahwa nasabah yang puas memiliki loyalitas kepada kartu kredit Bank Mega.

Hasil penelitian ini didukung penelitian sebelumnya yang dilakukan oleh Endah Fitrianti (2011) dimana hasil pengujian statistik nilai $t$ atau secara parsial dan hasil uji $f$ atau secara simultan, variabel harapan nasabah, kualitas produk dan kepuasan nasabah memiliki pengaruh signifikan positif terhadap loyalitas pengguna kartu kredit PT. XYZ, Tbk. Dari hasil perhitungan analisis analisis determinasi $r 2=0,691$ hal ini menunjukkan bahwa sebesar 69,1\% loyalitas pengguna kartu kredit pada PT. XYZ, Tbk Makassar dipengaruhi oleh harapan nasabah (X1), Kualitas produk (X2), dan kepuasan nasabah (X3) dan sisanya30,9\% dipengaruhi oleh faktor-faktor lain di luar model penelitian.

\section{KESIMPULAN}

Dari apa yang telah penulis paparkan di atas, maka penulis menarik kesimpulan dalam penelitian ini adalah :

Dari tabel 20 model summary menunjukkan bahwa hasil perhitungan yang diperoleh dari nilai koefisien determinasi $\left(R^{2}\right)$ sebesar 0,294 yang diinterpretasikan bahwa variabel yang diteliti memiliki hubungan sebesar 29,4\%, artinya bahwa komunikasi interpersonal dipengaruhi oleh variabel fitur, durasi dan aktivitas sedangkan $70,6 \%$ merupakan faktor-faktor lain yang tidak diteliti dalam penelitian ini.

Dari Hasil Uji F menunjukkan bahwa secara bersama-sama antara promosi dan kepuasan nasabah memiliki pengaruh yang signifikan terhadap penjualan kartu kredit pada Bank Mega Cabang Makassar. (Hipotesis 1 terjawab)

Dari Hasil uji T menunjukkan bahwa promosi berpengaruh negatif dan signifikan terhadap penjualan kartu kredit pada Bank Mega Cabang Makassar, sedangkan untuk variabel kepuasan nasabah menunjukkan bahwa memiliki pengaruh dan signifikan terhadap penjualan kartu kredit pada Bank Mega Cabang Makassar (hipotesis 2 terjawab) 


\section{DAFTAR PUSTAKA}

---Panduan Penulisan Proposal dan Skripsi STIE Amkop Makassar.2017

Abdurrahman, Nana Herdianadan Achmad Sanusi. (2015), Manajemen Strategi Pemasaran, Bandung, CV Pustaka Setia

Abdullah Assegaf. 2001. Kamus Akuntansi

Alimiyah \& Padji. 2006. Kamus Istilah Akuntansi. Bandung : Yrama Widya,

Ali, Hasan . 2013. Marketing dan Kasus-Kasus Pilihan. Yogyakarta. CAPS (Center For Academic Publishing Service)

Alex S. Nitisemito, 2011, Manajemen Personalia, Ghalia Indonesia, Jakarta

Andrews, A. H., R. W. Blowey, H. Boyd, dan R. G. Eddy. 2009. Bovine Medicine Diseases and Husbandry of Cattle Second Edition. Blackwell Science, UK

Augusty, Ferdinand. 2006. Metode Penelitian Manajemen: Pedoman Penelitian untuk skripsi, Tesis dan Disertai Ilmu Manajemen. Semarang: Universitas Diponegoro

Barnes, James G., (2006). Secrets Of Customer Relationship Management, ANDI, Yogyakarta.

Basu, Swastha DH., Irawan. 2008. Manajemen Pemasaran Modern, Edisi Kedua, Cetakan Ke-tigabelas, Yogyakarta: Liberty Offset

.Boone,L.E. \& Kurtz, D.L.2009, Pengantar Bisnis, Jilid 2. Jakarta : Erlangga

Budidharmo, Susanto. 2010. Dasar-DasarManajemen Pemasaran. Yogyakarta: CAPS.

Budidharmo. 2010. Kamus Istilah Keuangan dan Investasi

Chu, A. H. C., dan Choi, J. N. (2005). Rethinking Procrastination: Positive Effects of "Active" Procrastination Behavior on Attitudes and Performance. The Journal of Psychology, 145 (3), 245-264.

Gitosudarmo, Indriyo dan Agus Mulyono. 2014. Prinsip Dasar Manajemen. Edisi 3. Yogyakarta: BPFE.

Grewal \& Levy. 2008. Marketing. New York : Mc-Graw Hill

Husein Umar. 2013. Metode Penelitian untuk Skripsi dan Tesis. Jakarta: Rajawali

Kerin, Roger A. \& Robert A. Peterson. 2015. Pemasaran Strategis, Kasus dan Komentar, Edisi Kesebelas jilid 1. Indeks: Jakarta

Kismono, Gugup. (2011). Bisnis Pengantar. Fakultas Ekonomi \& Bisnis UGM. Yogyakarta.

Kotler dan Keller.2009, Manajemen Pemasaran, Jilid I. Edisi Ke 13 Jakarta : Erlangga 
Kotler,Philip. \& Gary Armstrong. 2014. Principle Of Marketing 15 edition. New Jersey : Pearson Prentice Hall.

Kotler, Philip and Keller, Kevin Lane (2013), Manajemen Pemasaran, Jilid 1, Edisi 13, Erlangga

Kotler, Keller. 2010. Marketing Management (Edisi 14e). Pearson : England

Kusmono,H. Teman. (2009). Pengaruh Budaya Organisasi Terhadap Motivasi dan Kepuasan Kerja serta Kinerja Karyawan pada Sub Sektor IndustriPengolahan Kayu Skala Menengah di Jawa Timur. Jurnal Manajemen dan Kewirausahaan, Vol. 7 No. 2, September 2005: 171-188.

Madura, Jeff. 2010. Keuangan Perusahaan Internasional, Edisi Kedelapan. Jakarta : Salemba Empat

Mulyono, 2009, Manajemen Administrasi \& Organisasi Pendidikan, Yogyakarta: Ar-Ruzz Media

Ratmino dan Atij Septi Winarsih, Manajemen Pelayanan. (Yogyakarta: Pustaka Pelajar, 2005), hal. 524 Daryanto dan Ismanto Setyobudi, Konsumen dan Pelayanan Prima...., hal. 52

Philip Kotler dan Kevin Lane Keller, Manajemen Pemasaran, Jilid I, Edisi Indonesia, (Jakarta: PT. Prenhallindo, 2002), hal.54

Panduan Penulisan Skripsi,2016.STIE AMKOP Makassar

Sedarmayanti.2011. Manajemen Sumber Daya Manusia, Reformasi Birokrasi dan Manajemen Pegawai Negeri Sipil ( Cetakan Kelima). Bandung : PT. Refika Aditama

Suryana. (2010). Kewirausahaan: Pedoman Praktis, Kiat dan Proses Menuju Sukses. Jakarta: Salemba Empat.

Swastha, Basu dan T. Hani Handoko. 2014. Manajemen Pemasaran (Analisis Perilaku Konsumen). BPFE:Yogyakarta

Tjiptono,Fandy.2008, Strategi Pemasaran, Edisi 3, ANDI : Yogyakart. 